\title{
Brief Analysis on Multiple Effects of Solfeggio Teaching and Ear Training on Music and Art Education
}

\author{
Jiang Qinfeng \\ Xi'an Conservatory of Music, Xi'an, Shaanxi Province
}

Keywords: Solfeggio and ear training; Teaching, music and art education; Practice; Effectiveness

\begin{abstract}
The great value of music exists in human's spiritual expression and explicit aesthetic perception in the course of musical composition and appreciation. In musical composition and appreciation activities, solfeggio and ear training are of great importance. This paper makes a brief discussion on the multiple effects of solfeggio teaching and ear training on the practice of music and art education.
\end{abstract}

Art education is an aesthetic education that cultivates the ability to perceive, appreciate and create beauty. Music education refers to all organized, well-planned and purposeful academic teaching of music under certain social requirements, which influences students' emotions, thoughts and thinking quality as well as promotes their knowledge and skills. In music education and teaching, solfeggio and ear training is a basic course with strong requirements of techniques, which can be divided into two parts, namely solfeggio, and ear training. "Ear training" is a skill training course on the purpose of cultivating musical auditory ability. The quality of "ear training" directly affects the teaching results of solfeggio training and guides its further development. Similarly, solfeggio also constantly accelerates the formation and improvement of human's inner hearing, continuously enhancing "ear training" skills in the practice of "singing". Therefore, the two parts should not be separated in a rigid way, in that they are an organic unity. Ear is the organ of perceiving music, and hearing is the sensation of sound produced by auditory organ (ear) under the action of sound waves, which is also the main way for the beauty of music to be internalized into the ripples of the soul. The aim of solfeggio teaching and ear training is to cultivate comprehensive musical auditory ability that is pervading in all music practices, including music composition, performance and appreciation, and to produce profound influences on the achievements of music and art education.

The teaching of solfeggio and ear training is based on skill training. Through the practices of solfeggio and ear training, students can form a complete system of musical knowledge and acquire practicable skills as well as rich musical cultures, so as to contribute into the research and practice of various majors and categories in music and art education. This paper discusses on the multiple effects of solfeggio teaching and ear training on the practice of music and art education in the following aspects. 


\section{Promotion of Innovation on Students of Music Composition Major}

The contents of solfeggio teaching and ear training is to analyze and deconstruct the text symbols in musical works by using auditory ability, in order to clearly understand and restore the composer's writing ideas. Through the training of recognizing musical elements, the actual teaching of solfeggio and ear training in music composition major helps students understand and analyze the relationship and the way of combination between the elements in musical works, finally enabling them to understand the logical relationship in application of these elements.

The teaching task of music composition major is to cultivate students to use musical elements in different combinations to form various sound structures, finally to produce complete musical works. The essence of composition is that the composer designs and forms his works with musical text symbols using the auditory images generated in his inner world. Skill training on musical elements in the traditional teaching mode of solfeggio and ear training presents a good result on the development of students' musical auditory ability, and also produces obvious influences on the practice of music creation. However, "how to encourage the composition major students to consciously apply their auditory ability onto music practices" is a teaching problem that worth considering by all the solfeggio and ear training teachers. At the 2009 National Teaching Seminar for Undergraduate and Postgraduate of Solfeggio and Ear Training Major in Art Colleges, Zuo Jia, a solfeggio and ear training teacher of China Conservatory of Music, said "Strengthening students' adaptation and creation skills of solfeggio works can not only improve their solfeggio proficiency and the level of auditory ability, but also develop their innovative minds.". In solfeggio teaching and ear training, teachers can achieve a better teaching result by combining solfeggio with the actual situation of composition major. For instance, teachers can ask students to compose a solfeggio according to a specific training element in solfeggio course as the original material, or try to adapt a classical solfeggio instead. In this way, students can deeply understand the effectiveness of solfeggio teaching when reconstructing the classical works, and naturally abandon the incomplete recognition of solfeggio and ear training course. During the above process, teachers can not only guide the way of organizing works to students, but also improve the development of students' analysis ability by using musical hearing, which is undoubtedly a win-win result. Firstly, the above-mentioned creation and adaptation should focus on solfeggio and ear training with limited contents. The degree of difficulty of music works should meet the requirements of training curriculum, favorably integrating technology with music. Secondly, the most important elemental structure adopted in the works must conform to the requirements of certain section of element training in solfeggio and ear training course, and should hold the value of targeted training. This kind of teaching idea and method that closely related to the major requires teachers to seriously consider about material selection and teaching objectives, and regularly organize students to self-evaluate on teaching results. Thus, while improving the effect of solfeggio teaching and ear training, it also promotes the innovation of students in music composition major.

\section{Improvement on Comprehensive Ability of Students in Performance Major}

Although solfeggio and ear training is a basic subject of music, it has a profound influence that unconsciously laid on the whole art career of its learners. In the professional course of performance major, the level of solfeggio and ear training directly affects the performer's overall ability and his recognition of music interpretation. Facing students of music performance major, solfeggio teachers should fully apply their mind to the research of "the methods of making solfeggio teaching effectively guide students to perform music works and improves their comprehensive performance ability". At the same time, in teaching practices, teachers can also carry out targeted training with combination of aesthetic characteristics of different directions in performance major, stimulating 
students' enthusiasm at innovation and thinking in music performance.

In actual teaching, solfeggio and ear training teachers should train on students' comprehensive musical performance ability adapting to their different professional directions. On the one hand, students can be encouraged to produce a much deeper understanding of the works by the analysis of solfeggio teaching and melody structure. On the other hand, they can further understand the close tie of creation and performance (recreation) in the solfeggio skills training.

In the early music life, performance and creation were originally integrated together. In the era when music text symbols have not yet appeared or were imperfect, creation is embodied as performance activities. Impromptu creation or performance has been seen as means of the expression of folk music and the creation of professional music. "If music creation builds up the body of a musical work, then the music performance endows this body with a soul. The combination generates the vivid life of music." From this point of view, any musical work is only about visual symbols which can be transformed into auditory symbols only by performance or singing. However, any music notation can not record various kinds of complex expressions in music without omission, which makes every performance of the works reflect subtle shades of differences. Therefore, the performer's interpretation of the music tends to be of great importance. The interpretation with subjective initiative is a recreational activity of performers. Any song we heard is actually the result of the co-creation between the creator and the performer. Therefore, on one hand, the solfeggio teaching and ear training for students of performance major should be proceeded in an orderly way; on the other hand, solfeggio teachers should guide students to form their ability of sight-singing and inner hearing which is necessary to be a performer. As a good music performer, as soon as he gets the works to be performed, the first thing to do is to read the music score. When reading music score, the performer can not only stay at the level of recognition, but at the same time of "reading", his inner auditory system should transform the music into music lines flowing out from his heart, with which his heart can feel the beauty of the melody. That is undoubtedly the organic unity of the ability of "solfeggio" and "ear training" — the ultimate goal of solfeggio teaching — which can be achieved by strictly following the teaching law as well as

its scientific nature. Facing the students of performance major, the teacher should, first of all, guide students to comprehensively realize their role as performers in the process of artistic activities in the solfeggio class. To flawlessly perform a work, students should experience the emotion expressed by the composer through "sight singing" and subtly perceive the true sound beauty of the work by their auditory feedback in instrumental playing or singing performance. As a performer, using the ability acquired from Solfeggio teaching and ear training course, he can organically combine the music score (sight-playing) reading with auditory perception, apply the two links together on the recreation of works and creatively explore the soul behind the notes, finally to achieve a indefectible performance.

\section{Improvement on Music Appreciation Ability}

Music is originally an art about sound hearing, in that music delights human senses and moods as well as sublimates spirits. "Listening" can be divided into two categories: admiration and appreciation. Generally speaking, the common casual way of music listening in daily life is the behavior of music admiration, while music appreciation conducts the behavior that people rationally analyze and distinguish the advantages and disadvantages of a certain music work through auditory perception after accumulating rich experience of music appreciation. In other words, music appreciation is a relatively professional auditory ability. Therefore, in order to achieve the real purpose of appreciating, the music appreciation should not stay on the surface or on human senses, but explore deep into the sound structure and various forms and factors of music. Only in this way 
can people accurately grasp the "connotation" of musical works, truly understanding music. To achieve the above point, the first thing to do is to repeatedly listen to the same piece of music. Listening over and over again is the key to cultivate music appreciation. Human's ears can not only play a role in the practice of recognizing and transforming the world, but also enjoy a strong inherent aesthetic perception. The music hearing of human is developed accordingly to the opportunity of linking with music given by music appreciation. The more times we listen, the more impressed we are. And the more impressed we are, the deeper our emotional experience of musical works will be. Therefore, if the memory of music is accumulated, the admiration and appreciation of music will be greatly improved.

Solfeggio and ear training is a basic course for music majors. Its task is to train students in aspects such as sense of pitch, rhythm, tonality and music score reading, cultivate students' musical perception, comprehension, appreciation and creativity, enable them to have a good command of correct pitch, rhythm and basic emotional expression, so as to fulfil the requirements of sight singing, recording the fragments of songs and instrumental music, and analyzing the mode, tonality, rhythm, termination and phrase of the music works. The aim of this course is to cultivate excellent music appreciation, laying a solid foundation for the further study of music major in the future.

The basic requirement of professional music appreciation is to form good musical hearing. However, students' ability of music appreciation is varied greatly as a result of their different emotions and thoughts, living habits, education backgrounds, artistic accomplishment and perception ability. Fortunately, students can still enjoy the same or at least similar level of perception and evaluation ability in music appreciation if the solfeggio teaching and ear training course can help them enhance auditory ability. In solfeggio teaching, the composition of solfeggio etudes and the expression of musical tone and color will deeply affect students' understanding of works and their feelings of singing. In this way, students will further experience and understand the music composition through the "sight singing" learning with continuous accumulation, forming the ability of rational analysis on music works. Meanwhile, through the practice of "sight-singing", students can in reverse recognize the auditory effect in the works produced by musical hearing. This is a series of teaching activities. It plays a positive and effective role in students' understanding, creation and performance of music. It will directly influences the improvement of students' music appreciation, and then promote their comprehensive ability. Students can constantly improve themselves in understanding and interpreting music works.

\section{Conclusion}

Solfeggio and ear training is the basic course of all kinds of music majors, the foundation of social art education in the future, and a required skill that frequently used in teaching practice in music and art education, which produces great driving force in cultivating musical and artistic talents. The Solfeggio teaching and ear training should be introduced in a thorough research of the effective teaching approaches suitable for the subject itself as well as the music and art education, and a constant study on more effective teaching methods combined with creative teaching practice. While improving the quality of teaching activities in music majors, solfeggio and ear training course constantly reacts on itself, integrating and developing itself with other directions of music majors altogether.

\section{References}

[1] ZUO Jia. Exploration and Practice of Solfeggio Teaching for Composition Major in Art Colleges [J]. Musical Works, 2018(10).

[2] WANG Ci-zhao. Aesthetics of Music [M]. Beijing: Higher Education Press, 2000, p117-188. 
[3] GONG Xiao. Brief Analysis On the Role of Solfeggio Teaching in Music Education of Colleges and Universities [J]. Song of the Yellow River, 2017(21).

[4] PAN Wei. On the Cultivation of Improvisational Ability of Music Education Major by Solfeggio Training [J]. The New Voice of Yue-fu (The Academic Periodical of Shenyang Conservatory of Music), 2017(04).

[5] SUN Jia-guo. Formation of Scientific Thinking in Solfeggio Teaching [J]. HUANGZHONG (Journal of Wuhan Conservatory of Music, China), 2003(3).

[6] ZHAO Xiao-ping. Nearest Approaches and Structural Awareness to Harmony Training [J]. Journal of Xi'an Conservatory of Music, 2003(2). 